\title{
Evaluation of Rice (Oryza Sativa) Varieties Suitable for Organic Farming
}

\begin{abstract}
A field experiment was conducted to evaluate the rice varieties suitable for organic farming. The experiment was carried out in the rabi season of 2013-14 at Tamil Nadu Agricultural University, Coimbatore to study the yield, quality and economics of different rice varieties. The experiment was laid out in a RBD replicated thrice. The treatments consisted of 12 rice varieties viz., Bhavani, White ponni, Mappillai samba, Kitchili samba, IR 20, CO 43, CO(R) 48, CO(R) 51, CB 05022, KDML 105, Red kavuni and Jeeraga samba. The culture CB 05022 produced significantly higher grain yield of $4877 \mathrm{~kg} \mathrm{ha}^{-1}$ and registered a yield increase ranging from 32 to 82 per cent over the other varieties under evaluation. With regard to quality parameters, grains of the culture CB 05022 was medium slender based on the kernel length and L/B ratio. The highest net return of ${ }^{`} 40,015$ ha $^{-1}$ with $B: C$ ratio of 2.28 was realised under the rice culture CB 05022 followed by Kitchili samba (net return: ` 32,423 ha $^{-1}$; B:C ratio: 2.04 ) and Jeeraga samba (net return: ` 31,431 ha $^{-1} ; B: C$ ratio: 2.01). It is inferred that varieties and cultures differ widely among themselves when grown under organic farming. In terms of grain yield, quality and economics, the culture CB 05022 performed better under the organic production system.
\end{abstract}

Key words: CB 05022, Hulling percentage, Kitchili samba, Mappillai samba, Milling percentage, Red kavuni, Soil health.

\section{INTRODUCTION}

The chemical era of modern agriculture concentrates on maximum output but over looks input efficiency as a result of which it has not been sustainable. Growing awareness of health and environmental issues associated with indiscriminative uses of chemical inputs has led to the interest of alternate agriculture. Organic agriculture is one among the broad spectrum of production methods that are supportive of the environment (Ramesh et al. 2005). Choice of variety is more critical in organic farming than conventional farming. Therefore, it is important to carry out trials with selected rice varieties under organic farming in order to generate information and advice on the most appropriate choice of variety for quality rice production and its marketing. High yielding varieties, which respond well to chemical inputs, may not be always suitable for organic farming. Instead, varieties which are hardy with less pest and diseases occurrence and capable of giving acceptable yield especially in the early phase of conversion are ideal. Selection of varieties for organic rice production is not far different from the varieties selected for conventional production system. Hence, varieties that perform well in a region can be selected. As the current high yielding varieties and hybrids are inadvertently selected for high input systems, they are likely to behave differently under organic conditions thus necessary field scrutiny if grown organically. Conventional varieties have been developed with the aim of combining high productivity and standardized quality under high input conditions. Two main areas apparent where organic farming system differs most significantly from conventional farming systems are the soil fertility management and pest and disease management. The
Department of Agronomy, Tamil Nadu Agricultural University, Coimbatore-641 003, Tamil Nadu, India.

${ }^{1}$ Institute of Agriculture, Pallapuram (Post), Lalgudi (TK) Tiruchirappalli-621 712, Tamil Nadu, India.

Corresponding Author: P.M. Shanmugam, Institute of Agriculture, Pallapuram (Post), Lalgudi (TK) Tiruchirappalli-621 712, Tamil Nadu, India. Email: pms73@tnau.ac.in

How to cite this article: Kumari, K.V. and Shanmugam, P.M. (2020). Evaluation of Rice (Oryza Sativa) Varieties Suitable for Organic Farming. Indian Journal of Agricultural Research. 54(1): 71-76.

Submitted: 14-05-2019 Accepted: 05-09-2019 Published: 09-11-2019

varieties often perform differently in different environments due to genotype environment interactions; therefore it is important to evaluate rice varieties under organic farming systems. Keeping all the above information in view, a field experiment was carried out to study the evaluation of rice varieties suitable for organic farming with the objectives to identify rice varieties suitable for organic farming, study the yield and quality differences in rice varieties due to organic production practices.

\section{MATERIALS AND METHODS}

Field experiments were carried out during rabi season of 2013 - 2014 at Tamil Nadu Agricultural University, Coimbatore to evaluate the rice varieties suitable for organic farming. The experiment was laid out in a randomized block design (RBD) with twelve varieties as treatments which were replicated thrice viz., $\mathrm{V}_{1}$ : Bhavani, $\mathrm{V}_{2}$ : White ponni, $\mathrm{V}_{3}$ : Mappillai samba, $\mathrm{V}_{4}$ : Kitchili samba, $\mathrm{V}_{5}$ : IR 20, $\mathrm{V}_{6}$ : CO 43, 
Evaluation of Rice (Oryza Sativa) Varieties Suitable for Organic Farming

$\mathrm{V}_{7}: \mathrm{CO}(\mathrm{R})$ 48, $\mathrm{V}_{8}: \mathrm{CO}(\mathrm{R}) 51, \mathrm{~V}_{9}: \mathrm{CB} 05022$ (CO $43 \times$ ADT 39), $\mathrm{V}_{10}$ : KDML 105, $\mathrm{V}_{11}$ : Red kavuni and $\mathrm{V}_{12}$ : Jeeraga samba. Seeds of the rice varieties were treated with Pseudomonas fluorescens @ $10 \mathrm{~g} \mathrm{~kg}^{-1}$ of seeds and Azosprillum and Phosphobacteria @ $30 \mathrm{~g} \mathrm{~kg}^{-1}$ of seeds before sowing. Then seeds were soaked in water for $24 \mathrm{hrs}$ and incubated for another $12 \mathrm{hrs}$ for inducing sprouting. The sprouted seeds were broad casted in a well prepared raised bed nursery. Neem cake @ $50 \mathrm{~g} \mathrm{~m}^{-2}$ and vermicompost @ $200 \mathrm{~g} \mathrm{~m}^{-2}$ was applied. Seeds of dhaincha (Sesbania rostrata)@ 25 kg ha ${ }^{-1}$ was sown in the main field and biomass was incorporated as in situ at 45 DAS. The field was well puddled with tractor mounted cage wheel and leveled with leveling board. The treatment plots were formed according to the layout plan. After accounting $\mathrm{N}$ contribution from the daincha incorporation, the remaining $\mathrm{N}$ was meet out from the organic manures (vermicompost and neem cake). Twenty one days old rice seedlings were transplanted in the main field at a spacing of $25 \mathrm{~cm} \times 25 \mathrm{~cm} @$ one seedling per hill. Irrigation was given as and when required to maintain $2.5 \mathrm{~cm}$ height in early stage and $5 \mathrm{~cm}$ height of water in later stages of crop growth period up to 15 days before harvest. One cono weeder weeding was done at 20 DAT followed by two hand weeding at 30 and 60 DAT, respectively. Soil of the experimental field was clay loam, moderately drained grouped under Vertic Ustochrept (belonging to Noyyal series) taxonomical classification. The soil of the experimental field was low in available $\mathrm{N}$, medium in available $\mathrm{P}$ and high in available $\mathrm{K}$. The normal climatic condition of the location (mean of 60 years) is as follows: mean annual rainfall of Coimbatore is $657 \mathrm{~mm}$ distributed over 47 rainy days. The annual mean of maximum and minimum temperatures are 31.5 and $21.4^{\circ} \mathrm{C}$, respectively. The relative humidity ranges from 61 to 91 per cent in the forenoon and 14 to 68 per cent in the afternoon. The mean bright sunshine hours per day are 7.4 hours. During the experimental period, a total rainfall of $244.1 \mathrm{~mm}$ was received in 20 rainy days. The mean maximum and minimum temperatures were $30.5^{\circ} \mathrm{C}$ and $21^{\circ} \mathrm{C}$, respectively and the mean relative humidity was 85.60 per cent in the forenoon and 51.00 per cent in the afternoon. The prevailing market prices of commodities were used to work out the economics of different treatments.

\section{RESULTS AND DISCUSSION Yield Attributes}

\section{Productive tillers hill $^{-1}$}

The number of productive tillers hill ${ }^{-1}$ was significantly influenced by the rice varieties evaluated under organic farming (Fig 1). CB $05022\left(\mathrm{~V}_{\mathrm{g}}\right)$ produced significantly higher number of productive tillers hill ${ }^{-1}(14.73)$. The cultivar $\mathrm{CO}(\mathrm{R})$ $48\left(\mathrm{~V}_{7}\right)$ produced 12.13 numbers of productive tillers hill ${ }^{-1}$ which was on par with the variety White ponni $\left(\mathrm{V}_{2}\right)$. The Mappillai samba $\left(\mathrm{V}_{3}\right)$ produced lesser number of productive tillers hill ${ }^{-1}(5.00)$ compared with other rice varieties evaluated under organic farming. The reason of difference in effective tillers hill-1 is the genetic makeup of the variety, which is primarily influenced by heredity factors.

\section{Panicle length}

It is clearly evident from the results obtained that the panicle length was profoundly influenced by different varieties. Between the varieties, the higher panicle length of 28.53 $\mathrm{cm}$ was recorded in variety $\mathrm{CO}(\mathrm{R}) 48\left(\mathrm{~V}_{7}\right)$ followed by $\mathrm{CO}(\mathrm{R})$ $51\left(\mathrm{~V}_{5}\right)$ and Jeeraga samba $\left(\mathrm{V}_{12}\right)$. The variety Kitchili samba $\left(V_{4}\right)$ produced significantly shortest panicles $(18.75 \mathrm{~cm})$ and it was on par with $\mathrm{KDML} 105\left(\mathrm{~V}_{10}\right)$ (Fig 1). In the present investigation, the variety $\mathrm{CO}(\mathrm{R}) 48$ has higher $\mathrm{DMP}$ and hence length of the panicle was high in that variety. Also the results indicated that the differences in length of panicles might be due to genetic makeup of the varieties, which coincides with the observations of Irfan et al. (2005).

\section{Panicle weight}

Panicle weight was significantly influenced of by the different rice varieties evaluated under organic farming (Fig 1). CB $05022\left(\mathrm{~V}_{\mathrm{g}}\right)$ obtained higher panicle weight of $3.09 \mathrm{~g}$ which was on par with the variety White ponni $\left(\mathrm{V}_{2}\right)$ and it was superior to all other varieties. The lower panicle weight of $1.22 \mathrm{~g}$ was found in the KDML $105\left(\mathrm{~V}_{10}\right)$. Because of more number of filled grains panicle ${ }^{-1}$ in $C B$ 05022, there might be increase in panicle weight. Physiologically proper partitioning might have occurred from source to sink and as a result the panicle weight could have improved.

\section{Number of filled grains panicle ${ }^{-1}$}

Among the varieties CB $05022\left(\mathrm{~V}_{9}\right)$ recorded significantly higher number of filled grains panicle ${ }^{-1}(151.20)$ which was superior to other varieties followed by White ponni $\left(\mathrm{V}_{2}\right)$ and it was on par with $\mathrm{CO}(\mathrm{R}) 48\left(\mathrm{~V}_{7}\right)$, Red kavuni $\left(\mathrm{V}_{11}\right)$, CO 43 $\left(\mathrm{V}_{6}\right)$. The variety $\mathrm{KDML} 105\left(\mathrm{~V}_{10}\right)$ recorded significantly lower number of filled grains panicle ${ }^{-1}(45.33)$ compared with other varieties (Fig 1).

\section{Fertility percentage}

Bhavani $\left(V_{1}\right)$ obtained higher fertility percentage of 88.18 per cent because of less number of unfilled grains (12.28), which was followed by $\mathrm{CO}(\mathrm{R}) 48(84.43 \%)$ and culture $\mathrm{CB}$ 05022 (84.28\%). The lower fertility percentage of 77.90 , 70.87 and 68.93 was recorded in Mapillai samba, CO 43 and $\mathrm{CO}(\mathrm{R}) 51$, respectively (Fig 1 ).

\section{Thousand grain weight}

Higher 1000 grain weight (27.42 g) was recorded in Mappillai samba, which might be due to its larger grain size (Fig 1). The lower 1000 grain weight $(10.00 \mathrm{~g})$ was found in Jeeraga samba, because of its smaller grain size. Larger variation in grain weight may be due to diverse genetic makeup of cultivars and their differential response to prevalent environment during grain filling stage.

\section{Yield}

Grain yield: Perceptible variation in rice grain yield was realized in the evaluation of rice varieties under organic production. The culture CB 05022 produced higher grain 

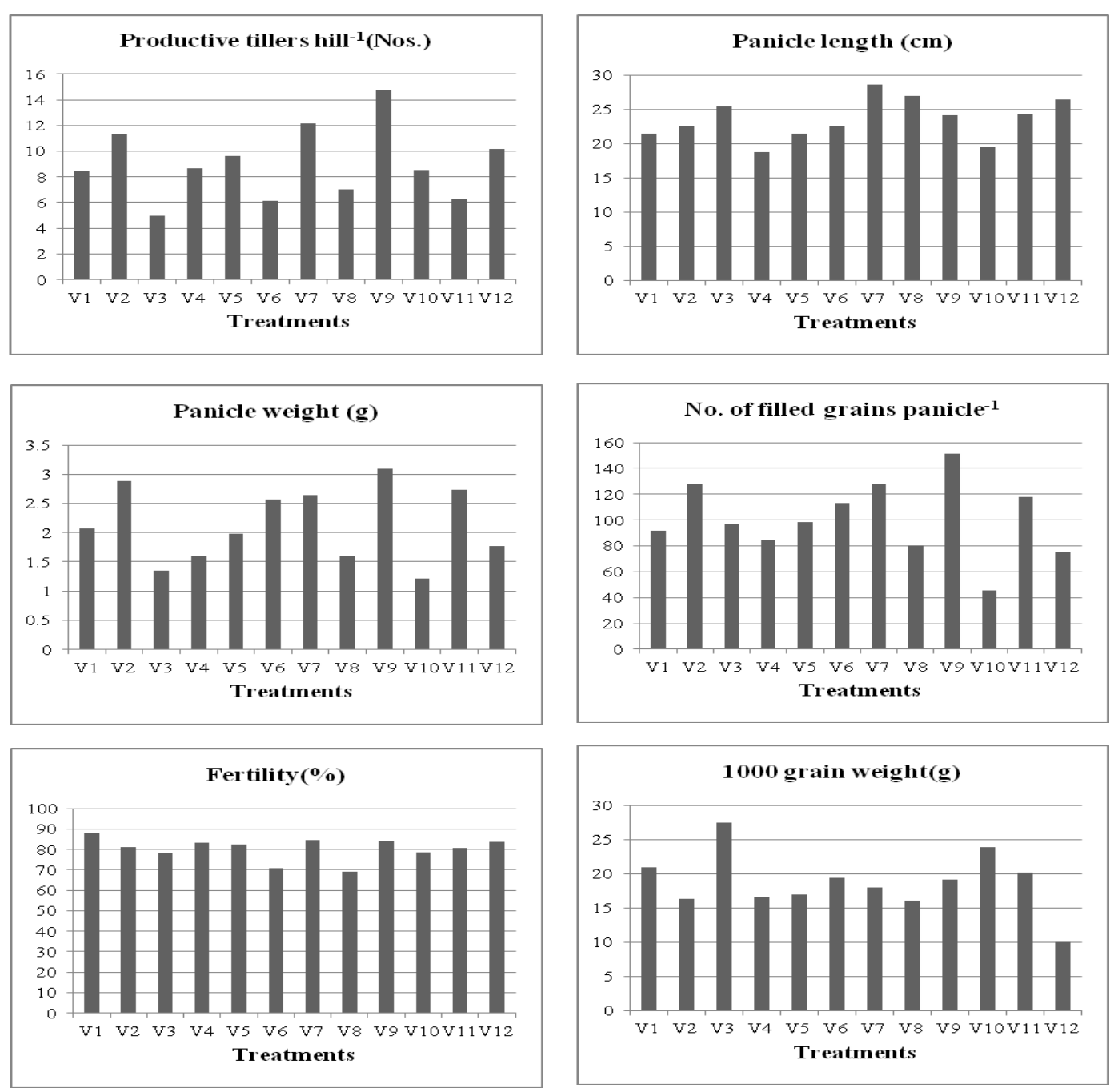

Fig 1: Yield attributes of rice varieties under organic farming.

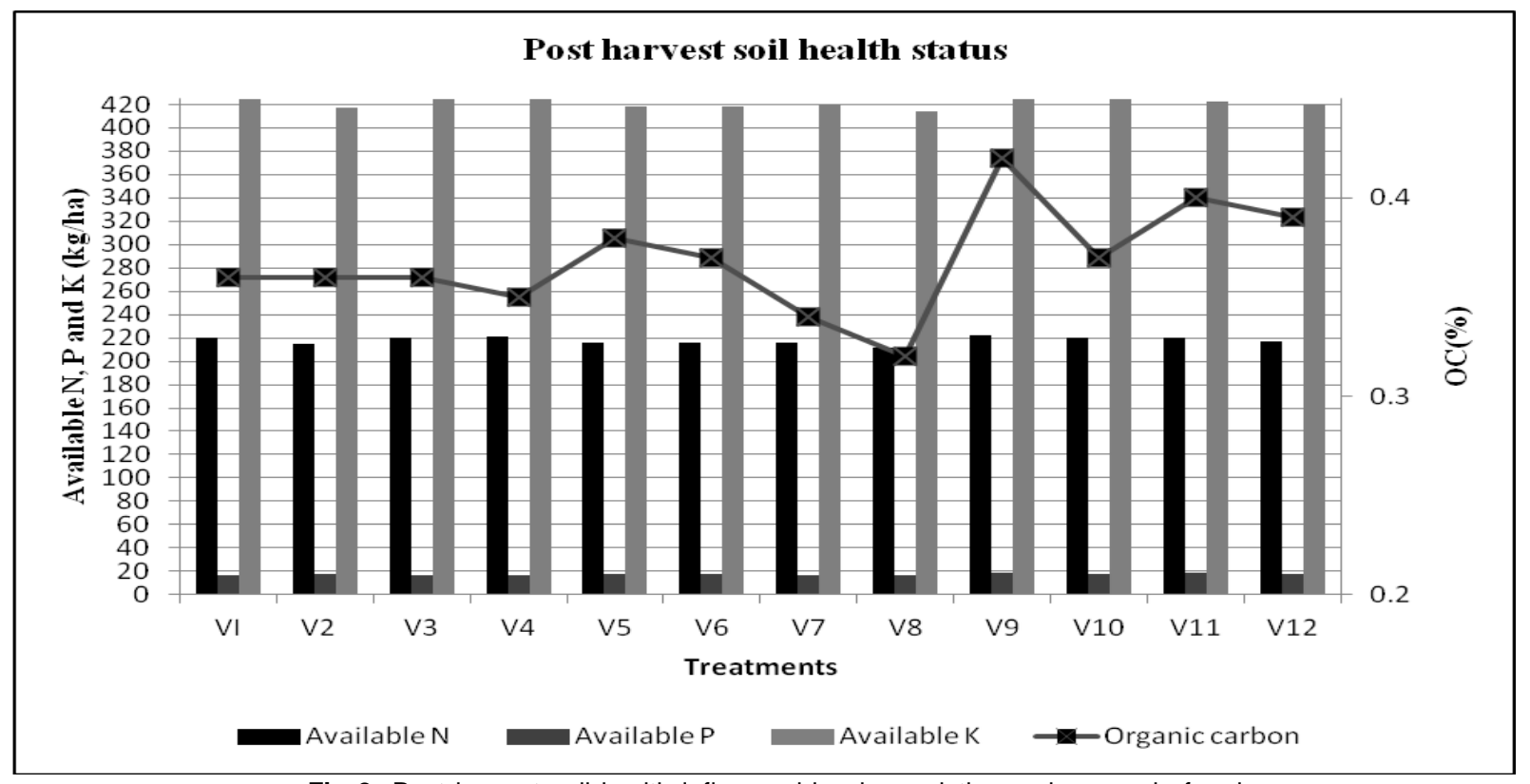

Fig 2: Post harvest soil health influenced by rice varieties under organic farming. 
yield of $4877 \mathrm{~kg} \mathrm{ha}^{-1}$ (Table 1) which was $32,51,52,58,60$, $65,67,67,70,74$ and 82 per cent yield increase, respectively over CO $48\left(\mathrm{~V}_{7}\right)$, White ponni $\left(\mathrm{V}_{2}\right)$, Kitchili samba $\left(\mathrm{V}_{4}\right)$, Bhavani $\left(\mathrm{V}_{1}\right)$, IR $20\left(\mathrm{~V}_{5}\right)$, Jeereaga samba $\left(\mathrm{V}_{12}\right)$, Red kavuni $\left(\mathrm{V}_{11}\right)$, Mappillai samba $\left(\mathrm{V}_{3}\right), \mathrm{CO}(\mathrm{R}) 43\left(\mathrm{~V}_{6}\right), \mathrm{KDML}$ $105\left(\mathrm{~V}_{10}\right)$ and $\mathrm{CO}(\mathrm{R}) 51\left(\mathrm{~V}_{8}\right)$. The yield mainly depends on the yield contributing characters like the number of effective tillers hill $^{-1}$, number of grains panicle ${ }^{-1}$, thousand grains weight and number of spikelet sterility. In the present investigation the culture CB 05022 had improved growth parameters viz., number of tillers, LAI, DMP and CGR. As a result of increased growth characters observed under this culture, the yield components viz., productive tillers hill ${ }^{-1}$ (14.73), filled grains panicle ${ }^{-1}(151.20)$ and panicle weight $(3.09 \mathrm{~g})$ were also higher compared with other varieties. Because of enhanced growth characters with improved yield components, which led to higher grain yield in the culture CB 05022. Lowest grain yield was recorded in CO(R) 51 . This was quite natural due to lower tiller production, DMP and LAI. Balasubramaniyan (2003) noted that rice variety Ponni grew taller than IR 20 and recorded more panicle length $(28.9 \mathrm{~cm})$, filled grains $(94.70)$ and grain filling percentage compared with IR 20 under the organic farming. Srilatha et al. (2011) reported that JGL-3855 rice variety recorded higher yield $\left(7054 \mathrm{~kg} \mathrm{ha}^{-1}\right)$ where compared to other varieties with organic production. Jagadeeshwar et al. (2012) reported that the varieties Sugandha samba produced higher grain yield $\left(4.4 \mathrm{t} \mathrm{ha}^{-1}\right)$ during kharif and Tellahamas (5.1 $\left.\mathrm{t} \mathrm{ha}^{-1}\right)$ during rabi under the organic nutrient sources. Rao et al. (2013) observed that rice variety RNR 2465 recorded the highest number of panicles (372), total grains (133), filled grains panicle ${ }^{-1}(105)$ and thousand grain weight $(23.04 \mathrm{~g})$ and it leads to higher grain $\left(4415 \mathrm{~kg} \mathrm{ha}^{-1}\right)$ and straw yield $\left(5865 \mathrm{~kg} \mathrm{ha}^{-1}\right)$ under the organic production systems.

\section{Straw yield}

Straw yield was significantly influenced by the different rice genotypes evaluated under organic farming. Mappillai

Table 1: Grain yield $\left(\mathrm{kg} \mathrm{ha}^{-1}\right)$, straw yield $\left(\mathrm{kg} \mathrm{ha}^{-1}\right)$ and economics of rice varieties under organic farming.

\begin{tabular}{|c|c|c|c|c|c|}
\hline Treatments & Grain yield & Straw yield & Cost of cultivation* & Gross Return* & B : C Ratio* \\
\hline $\mathrm{V}_{1}$ : Bhavani & 3080 & 4312 & 31190 & 44968 & 1.44 \\
\hline $\mathrm{V}_{2}:$ White Ponni & 3238 & 5474 & 31190 & 48686 & 1.56 \\
\hline $\mathrm{V}_{3}:$ Mappillai samba & 2926 & 7542 & 31220 & 62518 & 2.00 \\
\hline $\mathrm{V}_{4}:$ Kitchili samba & 3209 & 4991 & 31220 & 63643 & 2.04 \\
\hline$V_{5}: \operatorname{IR~} 20$ & 3054 & 4276 & 31190 & 36954 & 1.18 \\
\hline$V_{6}: \mathrm{CO} 43$ & 2872 & 5358 & 31190 & 36757 & 1.18 \\
\hline $\mathrm{V}_{7}: \mathrm{CO}(\mathrm{R}) 48$ & 3688 & 5378 & 31190 & 44947 & 1.44 \\
\hline $\mathrm{V}_{8}: \mathrm{CO}(\mathrm{R}) 51$ & 2676 & 5446 & 31190 & 34929 & 1.12 \\
\hline$V_{9}: C B 05022$ & 4877 & 6828 & 31190 & 71205 & 2.28 \\
\hline $\mathrm{V}_{10}: \mathrm{KDML} 105$ & 2800 & 3157 & 31220 & 53736 & 1.72 \\
\hline $\mathrm{V}_{11}$ : Red kavuni & 2950 & 5140 & 31220 & 59335 & 1.90 \\
\hline$V_{12}$ : Jeeraga samba & 2963 & 7199 & 31220 & 62651 & 2.01 \\
\hline$C D(P \leq 0.05)$ & 235 & 310 & & & \\
\hline
\end{tabular}

${ }^{*}$ Data statistically not analysed.

Table 2: Physical parameters of rice varieties under organic farming.

\begin{tabular}{|c|c|c|c|c|c|c|c|c|}
\hline Treatments & $\begin{array}{l}\text { Kernel } \\
\text { length } \\
(\mathrm{mm})\end{array}$ & $\begin{array}{l}\text { Grain } \\
\text { size }\end{array}$ & $\begin{array}{c}\text { Kernel } \\
\text { breadth } \\
(\mathrm{mm})\end{array}$ & Scale & $\begin{array}{l}\mathrm{L} / \mathrm{B} \\
\text { ratio }\end{array}$ & $\begin{array}{l}\text { Grain } \\
\text { shape }\end{array}$ & $\begin{array}{c}\text { Hulling } \\
\text { percentage }\end{array}$ & $\begin{array}{c}\text { Milling } \\
\text { percentage }\end{array}$ \\
\hline $\mathrm{V}_{1}$ : Bhavani & 5.6 & Medium & 1.9 & 4 & 2.95 & Medium & 78.0 & 72.8 \\
\hline$V_{2}:$ White Ponni & 5.6 & Medium & 1.9 & 4 & 2.95 & Medium & 84.0 & 74.0 \\
\hline $\mathrm{V}_{3}$ : Mappillai samba & 5.6 & Medium & 1.8 & 4 & 3.11 & Slender & 81.6 & 73.6 \\
\hline $\mathrm{V}_{4}$ : Kitchili samba & 5.9 & Medium & 1.8 & 4 & 3.28 & Slender & 74.8 & 68.0 \\
\hline$V_{5}:$ IR 20 & 5.7 & Medium & 1.9 & 4 & 3.00 & Medium & 80.4 & 71.2 \\
\hline$v_{6}: C O 43$ & 5.6 & Medium & 2.1 & 3 & 2.67 & Medium & 88.4 & 79.2 \\
\hline$V_{7}: C O(R) 48$ & 5.8 & Medium & 1.8 & 4 & 3.22 & Slender & 76.0 & 68.4 \\
\hline$V_{8}: C O(R) 51$ & 5.8 & Medium & 1.8 & 4 & 3.22 & Slender & 71.6 & 65.6 \\
\hline$V_{9}:$ CB 05022 & 5.9 & Medium & 1.9 & 4 & 3.11 & Slender & 70.0 & 60.0 \\
\hline $\mathrm{V}_{10}: \mathrm{KDML} 105$ & 7.0 & Long & 1.8 & 4 & 3.89 & Slender & 85.2 & 78.0 \\
\hline $\mathrm{V}_{11}$ : Red kavuni & 5.6 & Medium & 2.0 & 4 & 2.80 & Medium & 76.0 & 66.8 \\
\hline$V_{12}$ : Jeeraga samba & 4.0 & Short & 1.8 & 4 & 2.22 & Medium & 82.8 & 77.2 \\
\hline
\end{tabular}

${ }^{*}$ Data statistically not analysed. 
samba $\left(\mathrm{V}_{3}\right)$ recorded significantly higher straw yield of 7542 $\mathrm{kg} \mathrm{ha}^{-1}$ and followed by the variety Jeeraga samba $\left(\mathrm{V}_{12}\right)$ and CB $05022\left(\mathrm{~V}_{9}\right)$. The varieties White ponni $\left(\mathrm{V}_{2}\right), \mathrm{CO}(\mathrm{R}) 51$ $\left(\mathrm{V}_{8}\right), \mathrm{CO} 43\left(\mathrm{~V}_{6}\right)$ and $\mathrm{CO}(\mathrm{R}) 48\left(\mathrm{~V}_{7}\right)$ were produced statistically on par straw yield of $5474,5446,5358$ and 5378 $\mathrm{kg} \mathrm{ha}^{-1}$ respectively (Table 1). Significantly lesser straw yield was realized in KDML $105\left(\mathrm{~V}_{10}\right)$ with $3157 \mathrm{~kg} \mathrm{ha}^{-1}$.

\section{Economics}

The cost of cultivation was varied slightly in all varieties from (' 31,190 to $31,220 \mathrm{ha}^{-1}$ ). The highest net return of ${ }^{`} 40,015$ ha $^{-1}$ was recorded in $\mathrm{CB} 05022$ and with highest $\mathrm{B}: \mathrm{C}$ ratio of 2.28 because of higher grain yield and it was followed by Kitchili samba, Jeeraga samba and Mappillai samba (Net return: ' 32423, ' 31431 and ' 31298 ha $^{-1}$ with B:C ratio 2.04, 2.01 and 2.00, respectively). The lowest grain yield was recorded in CO 51 and KDML 105 but KDML105 was economically viable because the cost of produce was higher ( $17.50 \mathrm{~kg}^{-1}$ ) with B:C ratio of 1.72 (Table 1). The variety $\mathrm{CO}(\mathrm{R}) 51$ registered lowest net return of ${ }^{\prime} 3739 \mathrm{ha}^{-1}$ with $\mathrm{B}: \mathrm{C}$ ratio of 1.12. Income from a crop is determined by its yield level, produce market price and cost incurred on its cultivation. Eventually, under similar cost of production, the cultivars produced higher yields provide more returns and benefit per rupee invested. Hossain et al. (2008) observed that the $B: C$ ratio of rice variety Fakhre malakand was highest (2.36) compared to all other varieties under organic production. Rao et al. (2013) reported that rice variety RNR 2465 recorded higher gross returns ( $91233 \mathrm{ha}^{-1}$ ), net returns (' 45483 ha $^{-1}$ ) due to higher grain yield. Ranjitha et al. (2013) found that the variety KRH 2 recorded maximum $\mathrm{B}: \mathrm{C}$ ratio of 2.07 under SRI method of cultivation with the organic nutrient management practices.

\section{Physical Quality Parameters}

\section{Kernel length and breadth}

Among these varieties, KDML $105\left(\mathrm{~V}_{10}\right)$ obtained higher kernel length of $7 \mathrm{~mm}$ and classified long size category. Jeeraga samba $\left(V_{12}\right)$ recorded kernel length of $4.00 \mathrm{~mm}$ and classified as short. The other varieties, Bhavani $\left(\mathrm{V}_{1}\right)$, White ponni $\left(V_{2}\right)$, Mappillai samba $\left(V_{3}\right)$, CO $43\left(V_{6}\right)$, Red kavuni $\left(\mathrm{V}_{11}\right)$, IR $20\left(\mathrm{~V}_{5}\right), \mathrm{CO}(\mathrm{R}) 48\left(\mathrm{~V}_{7}\right), \mathrm{CO}(\mathrm{R}) 51\left(\mathrm{~V}_{8}\right)$, Kitchili samba $\left(\mathrm{V}_{4}\right)$ and CB $05022\left(\mathrm{~V}_{9}\right)$ were registered the kernel length ranging from 5.6-5.9 $\mathrm{mm}$ and they were classified as medium size category (Table 2). The variety $\mathrm{CO} 43\left(\mathrm{~V}_{6}\right)$ variety recorded numerically higher kernel breadth of $2.1 \mathrm{~mm}$, and it was grouped under Scale 3. The all other varieties evaluated were registered kernel breadth ranging from 1.8 to $2.0 \mathrm{~mm}$ and they were grouped under Scale 4 .

\section{Length breadth ratio}

Among the different rice varieties evaluated under organic farming, KDML $105\left(\mathrm{~V}_{10}\right)$ recorded the higher L/B ratio of 3.89 and classified as slender grain shape group. The varieties like Kitchili samba $\left(V_{4}\right), C O(R) 48\left(V_{7}\right), C O(R) 51$ $\left(\mathrm{V}_{8}\right)$, Mappillai samba $\left(\mathrm{V}_{3}\right)$ and culture $\mathrm{CB} 05022\left(\mathrm{~V}_{9}\right)$ were recorded $L / B$ ratio ranging from 3.28 to 3.11 and comes under slender grain shape category (Table 2). Remaining varieties Bhavani $\left(\mathrm{V}_{1}\right)$, White ponni $\left(\mathrm{V}_{2}\right)$, IR $20\left(\mathrm{~V}_{5}\right), \mathrm{CO} 43$ $\left(V_{6}\right)$, Red kavuni $\left(V_{11}\right)$ and Jeeraga samba $\left(V_{12}\right)$ were classified as medium in grain shape.

\section{Hulling and milling percentage}

Varieties evaluated under organic production, $\mathrm{CO} 43\left(\mathrm{~V}_{6}\right)$ obtained higher hulling percentage $(88.4 \%)$ followed by KDML $105\left(\mathrm{~V}_{10}\right)$, White ponni $\left(\mathrm{V}_{2}\right)$, Jeeraga samba $\left(\mathrm{V}_{12}\right)$, Mappillai samba $\left(V_{3}\right)$, IR $20\left(V_{5}\right)$, Bhavani $\left(V_{1}\right), C O(R) 48$ $\left(\mathrm{V}_{7}\right)$, Red kavuni $\left(\mathrm{V}_{11}\right)$, Kitchili samba $\left(\mathrm{V}_{4}\right), \mathrm{CO}(\mathrm{R}) 51\left(\mathrm{~V}_{8}\right)$ (Table 2). The culture CB $05022\left(\mathrm{~V}_{9}\right)$ registered lower hulling percentage $(70.0 \%)$. The seventy percent or more are the desirable hulling characteristics for rice (Rita and Sarawgi, 2008). The same trend was followed in milling percentage of various rice varieties evaluated under organic production.

\section{Post harvest soil nutrient status}

In present investigation, the soil available $\mathrm{N}$ was high in the culture CB $05022\left(222 \mathrm{~kg} \mathrm{ha}^{-1}\right)$ followed by Kitchili samba, Mappillai samba, KDML 105, Bhavani, Red kavuni and Jeeraga samba and it was ranged from 217 to $221 \mathrm{~kg} \mathrm{ha}^{-1}$ (Fig 2). By increasing the microbial load nutrient status level was increased. In the present study, the culture CB 05022 has higher population of microbes so it will reflect higher nutrient status of soil. The culture CB 05022 was recorded significantly higher available $\mathrm{P}$ of $18.8 \mathrm{~kg} \mathrm{ha}^{-1}$ and lower in $\mathrm{CO}(\mathrm{R}) 51\left(16.1 \mathrm{~kg} \mathrm{ha}^{-1}\right)$. Available $\mathrm{K}$ in soil was higher in the variety Kitchili samba of $429 \mathrm{~kg} \mathrm{ha}^{-1}$ and $\mathrm{OC}$ was high in the plot with CB $05022(0.42 \%)$.

\section{CONCLUSION}

Organic farming may not lead to higher production and income in the short run as its returns are of long term nature. It is initially a soil building process. Organic farming systems ensures built in capacity to maintain and increase soil health and fertility leading to sustained increase in yield and production and low variability of crops thus results in stabilization and a high jump in income and sustainability in agriculture. Based on the experimental results it may be concluded that the varieties varied widely among themselves for various parameters recorded under organic production system. In terms of yield, quality and economics, the culture CB 05022 was superior under organic farming. Kitchili samba, Mappillai samba and Jeeraga samba were the other promising varieties to support organic rice farming.

\section{REFERENCES}

Balasubramaniyan, P. (2003). Performance of cultivars, population and manuring in rice under organic farming. Madras Agricultural Journal. 90 (7-9): 530-532.

Hossain, M.F., Islam, M.S., Rahman, M.M., Faruk, M.O., Ershad, M.G. (2008). Yield and quality performance of some aromatic rice varieties of Bangladesh. Journal of Agroforestry and Environment. 2(2): 155-158.

Irfan, M., Muhammad, T., Amin, M., Jabbar, A. (2005). Performance of yield and other agronomic characters of four wheat 
(Triticum aestivum L.) genotypes under natural heat stress. International Journal of Botany. 1(2): 124-127. Jagadeeshwar, R., Ramagopala varma, N., Gopal reddy, B., Narsimha Reddy, P., Surdender, C.H., Vanishree, S. (2012). Evaluation of different organic nutrient sources and varieties for organic rice (Oryza sativa L.) production. Journal of Research ANGRAU. 40(3): 6-8.

Ramesh, P., Mohan Singh, Subba Rao, A. (2005). Organic farming: Its relevance to the Indian context. Current Science. 88 (4): 561-568.

Ranjitha, P.S., Mahender Kumar, R., Jayasree, G. (2013). Evaluation of rice (Oryza sativa L.) varieties and hybrids in relation to different nutrient management practices for yield, nutrient uptake and economics in SRI. Annals of Biological Research.
4(10): 25-28.

Rao, K.T., Upendra Rao, A., Seetha Ramu, P., Sekhar, D., Venugopala Rao, N. (2013). Effect of organic manures on performance of scented varieties of rice in high altitude areas of Andhra Pradesh. International Journal of Current Microbiology and Applied Sciences. 2: 339-346.

Rita, B. and Sarawgi, A.K. (2008). Agro morphological and quality characterization of badshah bhog group from aromatic rice germplasm of Chhattisgarh. Bangladesh Journal of Agricultural Research. 33: 479-492.

Srilatha, M., Sharma, S.H.K., Bhanu Rekha, K., Varaprasad, A. (2011). Production potential of Rice (Oryza sativa L.) varieties under different nitrogen levels. Journal of Agriculture Sciences. 20(5): 192-200. 